\title{
Peran Corporate Governance Sebagai Pemoderasi Hubungan Tax Management dengan Kualitas Laba
}

Riwayat Artikel: Diterima 12 Okt 2015 Direvisi 22 Nop 2015 Disetujui 2 Des 2015

NI KOMANG ANGGRENI'; NYOMAN K. A. M. PUTRA'; I NYOMAN P. YASA ${ }^{2 * 1}$

${ }_{1}^{1}$ Program Studi Akuntansi, Universitas Mahasaraswati, Jl. Kamboja No. 11 A Denpasar, Bali, Indonesia. 2Program Studi Akuntansi, Universitas Pendidikan Ganesha, Jalan Udayana No.11 Singaraja, Indonesia.

*Corresponding Author, E_mail address: putrayasanyoman11@gmail.com

\begin{abstract}
This study aims to knows the effect of tax management, managerial ownership, institutional ownership to earnings quality a company listed on Indoneisa Stock Exchange. This study focused on manufacturing companies listed in Indonesia Stock Exchange for the period 2008-2013. The sampling method used is purposive sampling. Data were analyzed using moderated regression analysis (MRA). The results showed that the tax management negatively affect earnings quality, managerial ownership does not affect the tax relationship management and the quality of earnings and strengthen institutional ownership tax is a negative relationship management to the quality of earnings.

Keywords: Tax Management; Managerial Ownership; Institutional Ownership; Earnings Quality
\end{abstract}

\section{ABSTRAK}

P)enelitian ini bertujuan untuk mengetahui pengaruh manajemen pajak, kepemilikan manajerial dan kepemilikan institusional terhadap kualitas laba pada perusahaan manufaktur yang terdaftar di Bursa Efek Indonesia. Penelitian ini difokuskan pada perusahaan manufaktur yang terdaftar di Bursa Efek Indonesia untuk periode 2008-2013. Metode pengambilan sampel yang digunakan adalah purposive sampling. Teknik analisis data menggunakan moderated regression analysis (MRA). Hasil penelitian menunjukkan bahwa tax management berpengaruh negatif terhadap kualitas laba, kepemilikan manajerial tidak berpengaruh terhadap hubungan tax management dan kualitas laba dan kepemilikan institusi memperkuat hubungan negatif tax management terhadap kualitas laba.

Kata Kunci:Tax Management, Kepemilikan Manajerial, Kepemilikan institusi dan Kualitas Laba

\section{PENDAHULUAN}

Menurut Ikatan Akuntan Indonesia (IAI,2009), laporan keuangan perusahaan bermanfaat sebagai sumber informasi dalam mengukur nilai perusahaan sebagai dasar pengambilan keputusan ekonomi. Salah satu informasi yang terdapat dalam laporan keuangan adalah berkaitan dengan laba. Menurut Wijayanti (2006) informasi yang terkandung di dalam laba (earnings) mempunyai peran sangat penting bagi pihak-pihak yang berkepentingan terhadap suatu perusahaan. Pihak internal dan eksternal perusahaan menggunakan laba sebagai dasar pengambilan keputusan seperti pemberian kompensasi dan pembagian bonus kepada manajer, pengukur prestasi atau kinerja manajemen, dan dasar penentuan besarnya pengenaan pajak.

Pada prakteknya, perusahaan meng-hitung dua versi laporan keuangan setiap tahunnya, yaitu laporan keuangan ber-dasarkan Generally Accepted Accounting Principles (GAAP) dan laporan keuangan yang dihitung berdasarkan ketentuan perpajakan yang berlaku (Deviana, 2010). Pajak saat ini diandalkan sebagai sumber pendapatan utama pemerintah, karenanya pemerintah membuat peraturan yang dapat memaksimalkan penerimaan pajak (Firman, 2013). Bagi perusahaan, pajak 
merupakan beban pengeluaran yang dapat menurunkan laba bersih, sehingga manajer berusaha meminimalkan kewajibannya (Boynton, 1992, Desai dan Dharmapala, 2006).

Dalam hal pajak, manajemen dapat memilih strategi tax management yang bermanfaat bagi perusahaan dalam jangka panjang (Firman, 2013). Tax management merupakan upaya perusahaan dalam hal penanganan pembayaran pajak mulai dari perencanaan, pelaksanaan, dan pengendalian (Irawan dan Farahmita, 2012). Perencanaan pajak dilakukan untuk efisiensi pembayaran pajak. Perusahaan melakukan tax manage-ment atau tax planning untuk meminimalkan kewajiban pajak, melalui legal tax avoidance, yaitu penghindaran pajak sesuai peraturan pajak dengan cara mengetahui jenis transaksi yang menguntungkan perusahaan dari sisi penghematan pajak (Firman, 2013).

Corporate governance juga berkaitan dengan manajemen laba dan kualitas laba (Klein, 2002; Givoly dan Hayn, 2010). Agency theory memandang perbedaan kepentingan principal dan agen, masingmasing berusaha memaksimalkan kepenti-ngannya. Konflik yang muncul antara keduanya dapat mempengaruhi kualitas laba. Corporate governance berhubungan dengan tax management karena membayar pajak yang kecil dianggap adanya penghematan uang untuk kepentingan kesejahteraan pemegang saham (Chen et al., 2009) karenanya direksi dan CEO memegang peranan penting dalam menentukan strategi tax management (Minnick dan Noga, 2010).

Penelitian ini dilakukan untuk menge-tahui bagaimana pengaruh tax management, kepemilikan manajerial dan kepemilikan institusi terhadap kualitas laba. Perbedaan penelitian ini dengan penelitian sebelumnya adalah pada penelitian ini menggunakan variabel corporate governance sebagai pemoderasi sedangkan penelitian sebelumnya corporate governance digunakan sebagai variabel bebas, serta alat analisis yang digunakan adalah moderate regression analysis yang sebelumnya menggunakan poll regression (Firman,2013)

\section{TINJAUAN LITERATUR DAN PERUMUSAN HIPOTESIS \\ KUALITAS LABA}

Bellovary et al. (2005) mendefinisikan kualitas laba sebagai kemampuan laba dalam merefleksikan kebenaran laba dan mem-prediksi laba dimasa mendatang, dengan acuan stabilitas dan persistensi laba. Laba persisten merupakan indikator kemampuan laba dalam membayar dividen dimasa mendatang, dapat dikatakan pertanggung-jawaban manajer perusahaan dalam pengelolaan sumber daya yang dipercayakan kepada mereka. Pentingnya persistensi laba akhirnya menjadi perhitungan lain di dalam pengambilan keputusan (Fanani, 2010). Persistensi laba sebagai komponen yang memiliki nilai prediktif atas harapan laba, memiliki relevansi dengan book-tax differences (Firman, 2013). Book-tax differences merupakan informasi yang dapat membantu investor dalam menentukan kualitas laba dan nilai perusahaan.

\section{TAX MANAGEMENT}

Tax management merupakan pelaksa-naan dari peran pengaturan dan pengawasan dalam bidang perpajakan yang bersifat rutin, karena bersangkutan dengan transaksi yang berulang kali terjadi bertujuan untuk meminimalisasi tax exposure atau risiko hutang pajak (www.ortax.org, 2015). Minnick dan Noga (2010) mengartikan tax management sebagai kemampuan untuk membayar jumlah yang lebih sedikit atas pajak dalam jangka waktu yang panjang. Menurut Irawan dan Farahmita (2012) tax management merupakan upaya perusahaan dalam hal penanganan pembayaran pajak mulai dari perencanaan, pelaksanaan, dan pengendalian. 
Peraturan pajak memiliki banyak keten-tuan yang memungkinkan perusahaan untuk mengurangi pajak secara benar tanpa melanggar hukum (Irawan dan Farahmita, 2012). Suandy, seperti dikutip oleh Suarningrat dan Setiawan (2013), menga-takan bahwa tax management mempunyai dua tujuan, yaitu menerapkan peraturan pajak secara benar dan usaha efisiensi untuk mencapai laba yang seharusnya.

\section{LABA AKUNTANSI DAN LABA FISKAL}

Chariri dan Ghozali (2007) menyatakan bahwa laba adalah laba akuntansi yang merupakan selisih pengukuran pendapatan dan biaya. PSAK 46 (Revisi 2014) mendefinisikan laba akuntansi sebagai laba atau rugi bersih selama satu periode sebelum dikurangi beban pajak. Menurut Statement of Financial Accounting Concept (SFAC) No. 1, informasi laba memiliki manfaat dalam menilai kinerja manajemen, membantu mengestimasi kemampuan laba yang repre-sentatif dalam jangka panjang, memprediksi laba dan menaksir risiko dalam investasi. Laba akuntansi mengandung makna bersih atau neto yaitu sebagai net income atau penghasilan bersih untuk suatu periode sedangkan dalam PSAK 46 (Revisi 2014) laba kena pajak atau laba fiskal (rugi pajak atau rugi fiskal) adalah laba (rugi) selama satu periode yang dihitung berda-sarkan peraturan yang ditetapkan oleh Otoritas Pajak atas pajak penghasilan yang terutang (dilunasi). Akibat adanya perbedaan dasar penyusunan laba berdasarkan akuntansi dan peraturan perpajakan, maka laba yang dihasilkan melalui proses akuntansi memberikan ukuran yang berbeda dalam pengukuran pendapatan dan beban, namun tetap dapat dibandingkan dengan laporan laba berdasarkan peraturan pajak (Plesko, 2004).

\section{CORPORATE GOVERNANCE (CG)}

Menurut Monks dan Minow (2004) corporate governance (CG) merupakan sebuah studi yang mempelajari hubungan direktur, manajer, karyawan, pemegang saham, pelanggan, kreditur dan pemasok terhadap perusahaan dan hubungan antar sesamanya. Cadbury Committee, seperti dikutip oleh Forum for Corporate gover-nance in Indonesia (FCGI), mengartikan corporate governance atau tata kelola perusahaan sebagai seperangkat peraturan yang mengatur hubungan antara pemegang saham, pengurus (pengelola) perusahaan, pihak kreditur, pemerintah, karyawan serta para pemegang kepentingan intern dan ekstern lainnya yang berkaitan dengan hak-hak dan kewajiban mereka, atau dengan kata lain suatu sistem yang mengatur dan mengendalikan perusahaan. The Institute Indonesia of Corporate Governance (IICG), dalam situsnya (www.icg.org), mendefinisikan corporate governance sebagai serangkaian mekanisme untuk mengarahkan dan mengendalikan suatu perusahaan agar operasional perusahaan berjalan sesuai dengan harapan para pemangku kepentingan.

\section{PENGARUH TAX MANAGEMENT TERHADAP KUALITAS LABA}

Aktivitas tax management di antaranya ditunjukkan dengan adanya perbedaan laba akuntansi keuangan (financial accounting income) dengan laba fiskal (taxable income) atau lebih dikenal dengan book-tax differences (Firman, 2013). Lev dan Nissim (2004) berargumentasi laba perusahaan memiliki kualitas tinggi ketika dapat memprediksi kejadian masa depan. Laba fiskal semestinya memberikan informasi kualitas laba perusahaan karena aturan pajak tidak mengijinkan estimasi sebagaimana GAAP (generally accepted accounting principles). Oleh karena itu agar pengambilan keputusan dapat dilakukan dengan baik, diperlukan suatu informasi tentang laba yang berkualitas. Kualitas laba seringkali dikaitkan 
dengan persistensi laba, karena persistensi laba merupakan salah satu komponen nilai prediktif laba dalam mengukur kualitas laba.

Hanlon (2005) menyatakan bahwa perusahaan yang memiliki beda temporer kena pajak besar, cenderung melakukan pre tax income yang persisten. Joos et al.(2000) dalam Djamaludin et al. (2008) mem-buktikan bahwa perusahaan dengan book tax differences besar baik positif (laba akuntansi lebih besar dari laba fiskal) maupun negatif (laba akuntansi lebih kecil dari laba fiskal) diduga memiliki kualitas laba yang rendah. Berdasarkan uraian diatas maka dapat diajukan hipotesis sebagai berikut:

$H_{1}$ : Tax management berpengaruh negatif terhadap kualitas laba.

\section{PENGARUH KEPEMILIKAN MANAJERIAL TERHADAP HUBUNGAN TAX MANAGEMENT DAN KUALITAS LABA}

Salah satu tujuan penerapan corporate governance adalah untuk mengatasi masalah yang muncul akibat konflik kepentingan antara pemilik perusahaan dengan mana-jemen. Manajemen tidak akan bertindak untuk kepentingan pemegang saham jika tidak bermanfaat bagi mereka sendiri (Irawan dan Farahmita, 2012). Jensen dan Meckling (1976) menyatakan bahwa proporsi kepemilikan saham yang dikontrol oleh manajer dapat mempengaruhi kebijakan-kebijakan perusahaan dan akan dapat menyejajarkan kepentingan antara prinsipal dan agent. Peranan kepemilikan manajerial menjadi berpengaruh pada perusahaan, manajer bukan hanya berperan sebagai manajer melainkan juga sebagai pemegang saham (Jumiati dan Ratnadi, 2013). Hal ini akan menjadikan manajer akan lebih giat untuk memenuhi keinginan dari pemegang saham.

Kepemilikan manajerial dapat digunakan untuk menentukan kualitas laba mendatang yang tercermin dari persistensi labanya, semakin pihak manajemen memiliki saham perusahaan berarti semakin besar rasa tanggung jawab manajer untuk memper-tanggung jawabkan laporan keuangan (Jumiati dan Ratnadi, 2014). Dengan memperbesar kepemilikan manajerial maka diharapkan manajemen dapat lebih transparan dan meningkatkan kinerja mana-jemen. Sebagai hasil peningkatan kinerja manajemen tersebut dengan sendirinya kinerja perusahaan juga akan meningkat. Kinerja perusahaan selama ini, pada umumnya, masih diukur melalui bottom-line performance (kinerja laba). Kinerja laba salah satunya dipengaruhi oleh efisiensi pembayaran pajak perusahaan (Wijayanti, 2006). Semakin efisien pengelolaan pajak perusahaan maka diharapkan akan semakin tinggi marjin laba yang dihasilkan perusahaan (Irawan dan Farahmita, 2012). Berdasarkan penjelasan diatas dapat ditarik hipotesis sebagai berikut :

$\mathrm{H}_{2}$ : Kepemilikan manajerial memoderasi terhadap hubungan tax management dan kualitas laba.

\section{PENGARUH KEPEMILIKAN INSTITUSI TERHADAP HUBUNGAN TAX MANAGEMENT DAN KUALITAS LABA}

Penelitian yang dilakukan Shleifer dan Vishney (1986) menyatakan bahwa pemilik institusional memainkan peran penting dalam memantau, mendisiplinkan dan mempengaruhi manajer. Mereka berpendapat bahwa seharusnya pemilik institusional berdasarkan besar dan hak suara yang dimiliki, dapat memaksa manajer untuk berfokus pada kinerja ekonomi dan menghindari peluang untuk perilaku mementingkan diri sendiri.

Adanya tanggung jawab perusahaan kepada fidusia, maka pemilik institusi memiliki insentif untuk memastikan bahwa manajemen perusahaan membuat keputusan yang akan memaksimalkan 
kesejahteraan pemegang saham (Annisa dam Kurniasih, 2012). Hasil penelitian yang dilakukan oleh Khurana dan Moser (2009) adalah besar kecilnya konsentrasi kepemilikan institusi maka akan mempengaruhi kebijakan pajak agresif oleh perusahaan, dan semakin besarnya konsentrasi short-term shareholder institusional akan meningkatkan kebijakan pajak agresif, tetapi semakin besar konsentrasi kepemilikan long-term share-holder maka akan semakin mengurangi tindakan kebijakan pajak yang agresif.

Manajemen akan cenderung oportunistik apabila memiliki insentif atas kinerja keuangan diantaranya melalui adanya perbedaan standar akuntansi keuangan dengan peraturan perpajakan yang menimbulkan book-tax differences (Tang, 2006). Berda-sarkan penjelasan diatas dapat dirumuskan hipotesis sebagai berikut:

$\mathrm{H}_{3}$ : Kepemilikan institusi memoderasi terhadap hubungan antara tax management dan kualitas laba.

\section{METODE PENELITIAN}

\section{MODEL PENELITIAN}

Untuk membantu dalam memahami dinamika variabel-variabel di atas, maka diperlukan suatu model penelitian. Landasan teori yang telah diungkapkan disusun hipotesis yang merupakan alur pikiran peneliti dan untuk menghindari adanya bias maka dalam penelitian ini juga menggunakan tiga variabel kontrol meliputi arus kas operasi (Penman, 2001), ukuran perusahaan (Manzon dan Plesko, 2002), dan kinerja perusahaan (Lev dan Nissim, 2004). Dengan demikian, model penelitian pengaruh tax management pada kualitas laba dan corporate governance sebagai variabel moderasi adalah sebagai berikut.

\section{LOKASI PENELITIAN}

Lokasi Penelitian dilakukan di Bursa Efek Indonesia (BEI) melalui situs resminya www.idx.co.id

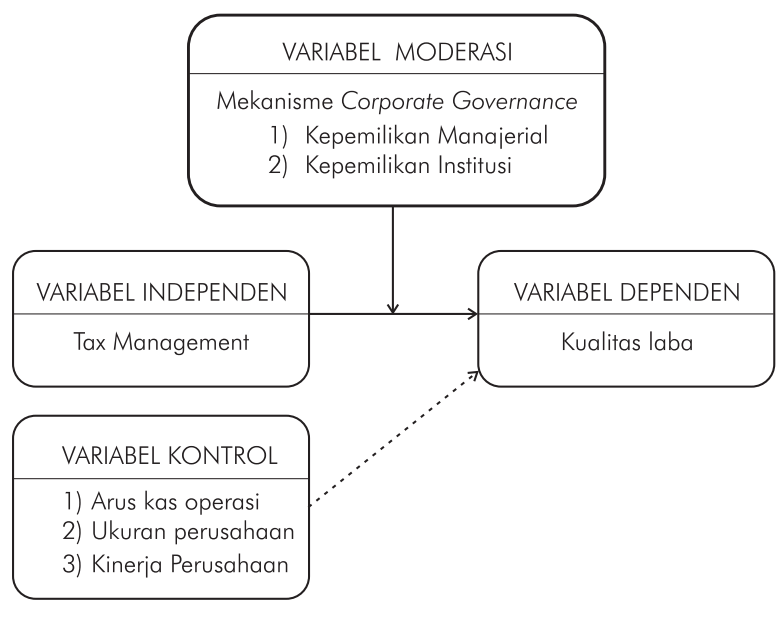

GAMBAR 1. MODEL PENELITIAN

dan Kantor Perwakilan BEI Denpasar, Jl. P.B. Sudirman 10X Kav. 2 Denpasar, didasarkan atas pertimbangan BEI merupakan salah satu tempat transaksi perdagangan saham dari berbagai jenis perusahaan yang ada di Indonesia dan BEI memberikan informasi yang lengkap tentang datadata keuangan perusahaan.

\section{OBJEK PENELITIAN}

Objek yang diteliti dalam penelitian ini adalah tax management, corporate governance dan kualitas laba pada perusahaan manufaktur yang terdaftar di BEI periode tahun 2008-2013.

\section{DEFINISI OPERASIONAL VARIABEL}

Kualitas Laba

Bellovary et al. (2005) mendefinisikan kualitas laba sebagai kemampuan laba dalam merefleksikan kebenaran laba dan memprediksi laba dimasa mendatang, dengan acuan stabilitas dan persistensi laba.

\section{Tax management}

Tax management merupakan pelaksa-naan dari peran pengaturan dan pengawasan dalam bidang perpajakan yang bersifat rutin, karena bersangkutan dengan transaksi yang berulang kali 
terjadi bertujuan untuk meminimalisasi tax exposure/risiko hutang pajak (www.ortax.org). Tax management dilihat dari perbedaan antara laba akuntansi dan laba fiskal (book-tax differences) (Firman, 2013).

\section{KEPEMILIKAN MANAJERIAL}

Kepemilikan manajerial merupakan proporsi pemegang saham dari pihak manajemen yang secara aktif ikut dalam pengambilan keputusan perusahaan (direktur dan komisaris). Dalam penelitian ini kepemilikan manajerial merupakan kepemi-likan saham oleh manajemen perusahaan yang diukur dengan persentase jumlah saham yang dimiliki oleh manajemen (Soliman et al., 2012).

\section{KEPEMILIKAN INSTITUSI}

Kepemilikan institusi merupakan kepemilikan saham oleh institusi keuangan, institusi berbadan hukum, institusi luar negeri, dana perwalian serta institusi lainnya pada akhir tahun. Dalam penelitian ini, Kepemilikan institusi diukur melalui besarnya persentase saham yang dimiliki oleh investor institusi (Soliman et al., 2012; Yunianto, 2013).

\section{VARIABEL KONTROL}

Variabel kontrol pertama yang digunakan adalah arus kas operasi berdasarkan arus kas operasi atau cash flow operation (CFO). CFO digunakan berdasarkan peneli-tian Penman (2001) bahwa persistensi laba juga ditentukan oleh komponen arus kas. CFO dihitung dengan total arus kas operasi dikurangi pos luar biasa (extraordinary items) ditambah beban pajak penghasilan.

Size atau ukuran perusahaan juga digunakan sebagai variabel penelitian berdasarkan Manzon dan Plesko (2002) bahwa ukuran perusahaan dapat memberikan kesempatan tax planning yang lebih besar sehingga dapat menimbulkan efek book-tax differences yang bias. Size diukur dengan menggunakan logaritma natural total asset.
Variabel kontrol terakhir yang digunakan adalah kinerja perusahaan yang diukur dengan return on asset (ROA). Penggunaan variabel kontrol ini adalah berdasarkan Lev dan Nissim (2004) bahwa ROA dapat mempengaruhi persistensi laba. ROA diperoleh dari laba bersih dibagi dengan total asset.

\section{METODE DAN TEKNIK PENENTUAN SAMPEL}

Populasi dalam penelitian ini adalah perusahaan manufaktur yang terdaftar di BEI tahun 2008-2013. Pemilihan populasi dilakukan pada perusahaan manufaktur yang terdaftar di bursa efek Indonesia karena sektor manufaktur merupakan sektor yang mampu memberikan kontribusi dan penyumbang pemasukan terbesar dalam penerimaan pajak pada tahun 2008-2013. Penentuan sampel dalam penelitian ini menggunakan metode purposive sampling dengan kriteria perusahaan yang dijadikan sampel penelitian adalah:

1) Perusahaan manufaktur yang terdaftar pada $B E I^{1}$ selama periode penelitian, yaitu tahun 2008 2013.

2) Perusahaan manufaktur yang menerbitkan laporan dalam mata uang rupiah.

3) Perusahaan tidak mengalami kerugian dan tidak mengalami kompensasi pajak akibat kerugian selama tahun pengamatan.

4) Perusahaan harus memiliki ketersediaan data seperti kepemilikan manajerial, kepemilikan institusi, dan data lainnya yang dibutuhkan dalam penelitian ini.

Adapun jumlah populasi perusahaan manufaktur yang terdaftar berturut-turut di BEI selama periode penelitian adalah sebanyak 119 perusahaan sedangkan sampel penelitian setelah disesuaikan dengan kriteria pemilihan sampel dalam penelitian ini sebanyak 12 sampel dengan jumlah observasi sebanyak 72 yang dapat dilihat pada tabel 1 . 


\section{METODE PENGUMPULAN DATA}

Metode pengumpulan data yang digunakan dalam penelitian ini adalah:

1) Studi pustaka, yaitu pengumpulan data yang dilakukan yaitu dengan mengolah literatur, artikel, jurnal, hasil penelitian terdahulu, maupun media tertulis lainnya yang berkaitan dengan topik pemba-hasan dari penelitian ini.

2) Studi dokumentasi, yaitu pengambilan data yang digunakan dengan mengumpulkan seluruh data sekunder dan seluruh informasi yang digunakan untuk menyelesaikan masalah yang ada dalam dokumen. Sumber-sumber data dokumenter seperti laporan keuangan perusa-haan yang menjadi sampel penelitian periode 2008-2013.

TABEL 1. DAFTAR PEMILIHAN SAMPEL

\begin{tabular}{lll}
\hline No & Keterangan & $\begin{array}{l}\text { Jumlah } \\
\text { Perusahaan }\end{array}$ \\
\hline 1 & $\begin{array}{l}\text { Perusahaan manufaktur yang } \\
\text { terdaftar di Bursa Efek Indonesia } \\
\text { periode 2008-2013 }\end{array}$ & 119 \\
2 & $\begin{array}{l}\text { Perusahaan tidak mengunakan mata } \\
\text { uang rupiah sebagai mata uang } \\
\text { pelaporan }\end{array}$ & $(20)$ \\
3 & $\begin{array}{l}\text { Perusahaan mengalami kerugian dan } \\
\text { melakukan kompensasi pajak }\end{array}$ & $(29)$ \\
4 & $\begin{array}{l}\text { Perusahaan dengan data tidak } \\
\text { ditemukan dan tidak lengkap }\end{array}$ & $(58)$ \\
\hline Jumlah sampel perusahaan & 12 \\
\hline $\begin{array}{l}\text { Jumlah observasi } \\
\text { (2008-2013) }\end{array}$ & 72 \\
\hline
\end{tabular}

\section{TEKNIK ANALISIS DATA}

\section{Statistik Deskriptif}

Statistik deskriptif memberikan gam-baran atau deskripsi suatu data yang dilihat dari nilai rata-rata (mean), standar deviasi, varian, maksimum, minimum, sum, range, kurtosis dan skewness (Ghozali, 2013). Statistik deskriptif yang digunakan dalam penelitian ini meliputi nilai minimum, maksimum, rata-rata, dan standar deviasi.

\section{Uji Asumsi Klasik}

Uji asumsi klasik dilakukan dalam penelitian ini untuk menguji apakah data memenuhi asumsi klasik. Hal ini untuk menghindari terjadinya estimasi yang bias mengingat tidak semua data dapat diterapkan regresi. Salah satu syarat untuk bisa menggunakan uji regresi adalah terpenuhinya uji asumsi klasik yang terdiri dari uji normalitas, uji multikolonieritas, uji heteros-kedastisitas dan uji autokorelasi.

\section{Analisis Regresi dengan Variabel Moderasi}

Moderated Regression Analysis (MRA) atau uji interaksi merupakan aplikasi khusus regresi berganda linear dimana dalam persamaan regresinya mengandung unsur interaksi (perkalian dua atau lebih variabel independen) (Liana, 2009). Model yang digunakan dalam MRA untuk menguji pengaruh tax management terhadap kualitas laba dan corporate governance sebagai variabel moderasi adalah sebagai berikut:

$$
\begin{aligned}
\Delta \mathrm{NI}= & \beta 0+\beta 1 \mathrm{BTD}+\beta 2 \mathrm{MO}+\beta 3\left(\mathrm{BTD}^{*} \mathrm{MO}\right)+\beta 4 \mathrm{IO}+ \\
& \beta 5\left(\mathrm{BTD}^{*} \mathrm{IO}\right)+\beta 6 \mathrm{CFO}+\beta 7 \mathrm{SIZE}+\beta 8 \mathrm{ROA}^{+} \varepsilon
\end{aligned}
$$

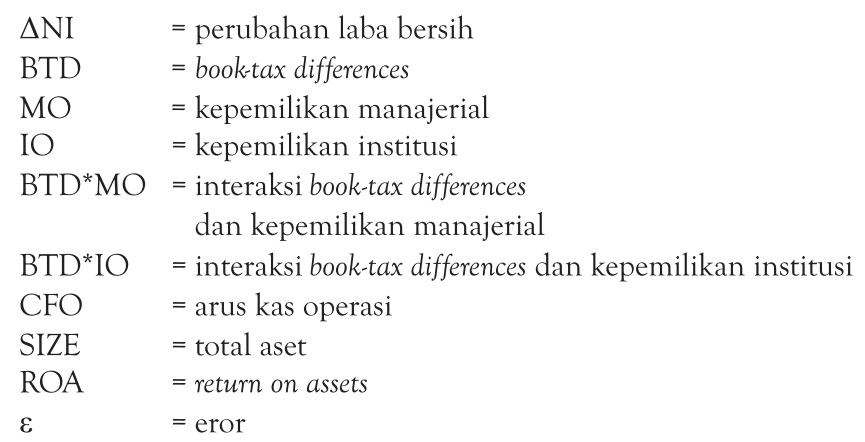

\section{Uji Kelayakan Model (Goodness of fit test)}

Penelitian ini menggunakan lebih dari satu variabel independen, maka untuk mengukur pengaruh variabel independen terhadap variabel dependen digunakan adjusted $\mathrm{R}^{2}$. Nilai adjusted $\mathrm{R}^{2}$ yang kecil berarti kemampuan variabel-variabel 
TABEL 2. HASIL STATISTIK DESKRIPTIF

\begin{tabular}{llllll}
\hline & N & Minimum & Maksimum & Mean & Std. Deviation \\
\hline BTD & 72 & $-3423,92$ & 1186,24 & $-112,96$ & 620,18 \\
MO & 72 & 0,02 & 25,61 & 4,91 & 8,37 \\
I0 & 72 & 32,22 & 95,65 & 64,92 & 19,07 \\
BTD*M0 & 72 & $-1886,76$ & 4808,85 & 19,41 & 625,07 \\
BTD*10 & 72 & -171367 & 94899,20 & $-3789,56$ & 35139,21 \\
CF0 & 72 & $-14055,53$ & 157256,77 & 2969,94 & 18646,70 \\
SIZE & 72 & 4,13 & 11,27 & 6,91 & 2,06 \\
ROA & 72 & 0,01 & 0,32 & 0,10 & $0,060,04$ \\
NIT & 72 & $-0,19$ & 0,24 & 0,01 & \\
Valid N & 72 & & & & \\
\hline
\end{tabular}

dependen amat terbatas selaian itu untuk menjawab hipotesis yang diajukan dalam penelitian ini juga menggunakan uji $\mathrm{F}$ yang pada dasarnya menunjukkan apakah semua variabel independen atau bebas yang dimasukkan dalam model mempunyai pengaruh secara bersama-sama terhadap variabel dependen/terikat (Ghozali, 2013) dan Uji $T$ yang pada dasarnya menunjukan seberapa jauh pengaruh satu variabel penjelas/ independen secara individual dalam menerangkan variasi variabel dependen (Ghozali, 2013). Uji t dapat dilakukan dengan melihat nilai signifikansi t masing-masing variabel. Jika nilai signifikansi dari masing-masing variabel independen lebih kecil dari 0,05 maka dapat dikatakan bahwa ada pengaruh variabel independen terhadap variabel dependen. Untuk arah, jika koefisien (+) maka berpengaruh positif, dan jika tanda koefisien negatif (-) maka berpengaruh negatif.

\section{HASIL DAN PEMBAHASAN}

STATISTIK DESKRIPTIF

Statistik deskriptif memberikan gambaran atau deskripsi suatu data, dalam penelitian ini statistik deskriptif dilihat dari nilai rata-rata (mean), nilai minimum, maksimum dan standar deviasi dari masing-masing variabel penelitian. Hasil dari analisis deskriptif dari variabel-variabel penelitian ini dapat dilihat pada Tabel 2.

\section{UJI ASUMSI KLASIK}

Salah satu syarat untuk bisa menggunakan uji regresi adalah terpenuhinya uji asumsi klasik yang terdiri dari uji normalitas, uji multikolonieritas, uji heteroskedastisitas dan uji autokorelasi. Hasil uji asumsi klasik disajikan sebagai berikut:

1) Uji Normalitas, bertujuan untuk menguji apakah dalam model regresi, variabel pengganggu atau residual memiliki distribusi normal atau tidak (Ghozali 2013). Berdasarkan hasil uji normalitas Kolmogorov-Smirnov di atas menun-jukkan bahwa nilai Kolmogorov-Smirnov sebesar 1,340 dengan nilai Sig. (2-tailed) sebesar 0,55 lebih besar dari á $(0,05)$, sehingga dapat disimpulkan bahwa residual berdistribusi normal.

TABEL 3. RINGKASAN UJI MULTIKOLENIARITAS

\begin{tabular}{lll}
\hline \multirow{2}{*}{ Variabel } & \multicolumn{2}{l}{ Collinearity Statistics } \\
\cline { 2 - 3 } & Tolerance & VIF \\
\hline BTD & 0,478 & 2,093 \\
MO & 0,593 & 1,687 \\
IO & 0,671 & 1,491 \\
BTD*MO & 0,828 & 1,208 \\
BTD*IO & 0,465 & 2,150 \\
CF0 & 0,979 & 1,021 \\
SIZE & 0,761 & 1,313 \\
ROA & 0,842 & 1,187 \\
\hline
\end{tabular}


2) Uji Multikolonieritas, bertujuan untuk menguji apakah model regresi ditemukan adanya korelasi antar variabel bebasnya (Ghozali 2013). Nilai cut off yang umum dipakai untuk menun-jukkan adanya multikolonieritas adalah nilai tolerance e" 0.10 atau sama dengan VIF d" 10.

Berdasarkan hasil uji multikolonieritas di atas menunjukkan bahwa nilai masing-masing variabel bebas memiliki nilai tolerance e- 0,10 dan nilai VIF d- 10. Sehingga disimpulkan bahwa tidak ada gejala multikolonieritas antar variabel bebas dalam model regresi.

3) Uji Autokorelasi, bertujuan untuk menguji apakah dalam model regresi linier ada korelasi antara kesalahan pengganggu pada periode $\mathrm{t}$ dengan kesalahan pengganggu pada periode $\mathrm{t}-1$ atau sebelumnya (Ghozali, 2013). Pengujian ada tidaknya autokorelasi dapat dilakukan dengan uji Durbin-Watson (DW Test). Model dikatakan terbebas dari autokorelasi positif atau negatif apabila nilai $\mathrm{d}_{\mathrm{u}}<\mathrm{d}<4-\mathrm{d}_{\mathrm{u}}$. Berdasarkan hasil uji Durbin-Watson di atas diperoleh bahwa nilai Durbin-Watson untuk persamaan regresi adalah 1,839 dengan tarif signifikan 5 persen, untuk $\mathrm{N}=72$ dan $\mathrm{K}=3$ diperoleh nilai $\mathrm{d}_{\mathrm{u}} 1,704$. Nilai $d$ dari persamaan tersebut berada pada $\mathrm{d}_{\mathrm{u}}<\mathrm{d}<4-\mathrm{d}_{\mathrm{u}}$ atau 1,704<1,839<2,296 maka dapat

disimpulkan tidak terdapat autokorelasi sehingga model ini layak digunakan untuk analisis selanjutnya.

4) Uji Heteroskedastisitas, bertujuan untuk menguji apakah model regresi terjadi ketidaksamaan varian dari residual satu pengamatan ke pengamatan lain (Ghozali, 2013). Untuk mendeteksi ada atau tidaknya heteroskedastisitas dapat dilakukan dengan menggunakan uji Glejser. Jika hasil uji Glejser menunjukkan nilai probabilitas signifikansi lebih besar dari 0,05 maka model regresi tidak mengandung heteroskedastisitas. Adapun hasil uji Glejser dapat di lihat pada tabel 4.

TABEL 4. RINGKASAN HASIL UJ HETEROSKEDASTISITAS

\begin{tabular}{ll}
\hline Model & Sig. \\
\hline (Constant) & 0,232 \\
BTD & 0,059 \\
MO & 0,220 \\
IO & 0,260 \\
BTD*MO & 0,673 \\
BTD*IO & 0,509 \\
CFO & 0,503 \\
SIZE & 0,702 \\
ROA & 0,704 \\
\hline
\end{tabular}

TABEL 5. RINGKASAN HASIL MOORAEDPEGPBSONANAISS

\begin{tabular}{|c|c|c|c|c|c|}
\hline \multirow{2}{*}{\multicolumn{2}{|c|}{ Model }} & \multicolumn{2}{|c|}{ Unstandardized Coefficients } & \multirow{2}{*}{$\dagger$} & \multirow{2}{*}{ Sig. } \\
\hline & & B & Std. Error & & \\
\hline \multirow[t]{9}{*}{1} & (Constant) &,- 051 & 032 & $-1,580$ & , 119 \\
\hline & BTD & $-4,0 E-005$ &, 000 & $-3,852$ &, 000 \\
\hline & MO &, 001 &, 001 &, 927 &, 357 \\
\hline & 10 &, 000 &, 000 & 1,179 & 243 \\
\hline & BTD*MO & ,11E-005 &, 000 & 1,414 &, 162 \\
\hline & BTD* 10 & $-6,3 \mathrm{E}-007$ &, 000 & $-3,371$ &, 001 \\
\hline & CFO & $-1,6 \mathrm{E}-007$ &, 000 &,- 661 &, 511 \\
\hline & SIZE &, 000 &, 002 &, 087 &, 931 \\
\hline & $\mathrm{ROA}$ &, 421 &, 081 & 5,173 &, 000 \\
\hline
\end{tabular}

Berdasarkan hasil uji Glejser diketahui bahwa tidak satupun dari variabel indepen-den yang terdiri dari tax management, kepemilikan manajerial, kepemilikan institusi, interaksi tax management dan kepe-milikan manajerial, interaksi tax management dan kepemilikan institusi, arus kas operasi, ukuran perusahaan, dan kinerja perusahaan memiliki nilai probabilitas kurang dari 0,05. Hasil ini menunjukkan bahwa bahwa model regresi dalam penelitian ini bebas dari heteroskedastisitas. Dari hasilhasil analisis di atas, maka dapat disimpulkan bahwa model regresi dalam penelitian ini telah memenuhi kriteria uji asumsi klasik.

ANALISIS REGRESI DENGAN VARIABEL MODERASI

Moderated Regression Analysis digu-nakan dalam 
penelitian ini untuk menjawab hipotesis yang diajukan dalam penelitian ini. Adapun hasil uji Moderated Regression Analysis (lihat Tabel 5).

Berdasarkan hasil analisis regresi Tabel 5 diperoleh persamaan sebagai berikut:

$$
\begin{aligned}
\Delta \mathrm{NI}= & -0,051-0,00004 \mathrm{BTD}+0,001 \mathrm{MO}+ \\
& 0,000011\left(\mathrm{BTD}^{*} \mathrm{MO}\right)+0,000 \mathrm{IO}- \\
& 0,00000063\left(\mathrm{BTD}^{*} \mathrm{IO}\right)-0,00000016 \mathrm{CFO}+ \\
& 0,000 \mathrm{SIZE}+0,421 \mathrm{ROA}
\end{aligned}
$$

\section{UJ KELAYAKAN MODEL (GOODNESS OF FIT TEST)}

Koefisien Determinasi $\left(\mathrm{R}^{2}\right)$

Koefisien Determinasi $\left(\mathrm{R}^{2}\right)$ pada intinya mengukur seberapa jauh kemampuan model dalam menerangkan variasi variabel dependen (Ghozali, 2013). Penelitian ini menggunakan lebih dari satu variabel independen, maka untuk mengukur pengaruh variabel independen terhadap variabel dependen digunakan adjusted $\mathrm{R}^{2}$. Nilai adjusted $\mathrm{R}^{2}$ yang kecil berarti kemampuan variabel-variabel dependen amat terbatas.

Berdasarkan hasil pengujian, nilai koefisien (Adjusted R Square) sebesar 0,284 atau 28,4 persen. Hal ini berarti 28,4 persen variabel kualitas laba dipengaruhi oleh tax management, kepemilikan manajerial dan kepemilikan institusi, sedangkan sisanya sebesar 71,6 persen dipengaruhi oleh faktor lainnya yang tidak dijelaskan dalam model regresi ini.

TABEL 6. RINGKASAN HASIL UJI F

\begin{tabular}{llll}
\hline Model & $F$ & Sig. \\
\hline 1 & Regression & 4,526 & 0,000 \\
& Residual & & \\
& Total & & \\
\hline
\end{tabular}

\section{Hasil Uji F}

Uji F pada dasarnya menunjukkan apa-kah semua variabel independen atau bebas yang dimasukkan dalam model mempunyai pengaruh secara bersama-sama terhadap variabel dependen/ terikat (Ghozali, 2013).

Berdasarkan hasil analisis diperoleh nilai $F_{\text {hitung }}$ 4,526 dengan sig. 0,000 yang lebih kecil dari 0,05, sehingga dapat disimpulkan bahwa seluruh variabel independen secara bersama-sama berpengaruh terhadap variabel dependen. Hasil ini menunjukkan bahwa model penelitian ini adalah fit atau layak.

\section{Hasil Uji t}

Uji t pada dasarnya menunjukan seberapa jauh pengaruh satu variabel penjelas/independen secara individual dalam menerangkan variasi variabel dependen (Ghozali, 2013). Uji t dapat dilakukan dengan melihat nilai signifikansi $t$, jika nilai signifikansi dari masing-masing variabel independen lebih kecil dari 0,05 maka dapat dikatakan bahwa ada pengaruh variabel independen terhadap variabel dependen. Untuk arah, jika koefisien $(+)$ maka berpengaruh positif, dan jika tanda koefisien negatif (-) maka

\begin{tabular}{|c|c|c|c|c|}
\hline \multirow{2}{*}{ Model } & \multicolumn{2}{|c|}{ Unstandardized Coefficients } & \multirow{2}{*}{$\dagger$} & \multirow{2}{*}{ Sig. } \\
\hline & B & Std. Error & & \\
\hline (Constant) &,- 051 &, 032 & $-1,580$ & 119 \\
\hline BTD & $-4,0 E-005$ &, 000 & $-3,852$ &, 000 \\
\hline MO &, 001 &, 001 &, 927 &, 357 \\
\hline 10 &, 000 &, 000 & 1,179 & 243 \\
\hline BTD*MO & ,11E-005 &, 000 & 1,414 &, 162 \\
\hline BTD*10 & $-6,3 \mathrm{E}-007$ &, 000 & $-3,371$ &, 001 \\
\hline $\mathrm{CFO}$ & $-1,6 \mathrm{E}-007$ &, 000 &,- 661 &, 511 \\
\hline SIZE &, 000 &, 002 &, 087 & ,931 \\
\hline ROA &, 421 & ,081 & 5,173 &, 000 \\
\hline
\end{tabular}
berpengaruh negatif. Adapun hasil uji t dapat dilihat pada tabel 7 .

TABEL 7. RINGKASAN HASIL UJI T 
Berdasarkan hasil uji statistik t pada Tabel 7, diperoleh hasil pengaruh tax management yang dilihat dari BTD mempunyai nilai $t_{\text {hitung }}$ sebesar 3,852 dengan tingkat signifikansi sebesar 0,000 yang berarti lebih kecil dari 0,05 dengan arah koefisien negatif. Hal ini berarti bahwa tax management yang dilihat dari BTD berpengaruh negatif terhadap kualitas laba, sehingga $\mathrm{H}_{1}$ diterima. Hasil penelitian ini mendukung penelitian yang dilakukan oleh Wijayanti (2006) yang menyatakan bahwa book-tax differences berpengaruh negatif signifikan terhadap persistensi laba. Semakin kecil book-tax differences akan meningkatkan persistensi laba, sehingga informasi tentang pajak perusahaan sebagaimana disajikan dalam laporan keuangan juga turut memberikan informasi mengenai kualitas laba.

Selanjutnya, pengaruh kepemilikan manajerial memoderasi terhadap hubungan tax management dan kualitas laba. Variabel interaksi antara tax management dan kepemilikan manajerial yang dilihat dari BTD* MO mempunyai nilai $t_{\text {hitung }}$ sebesar 1,414 dengan tingkat signifikansi sebesar 0,162 yang berarti lebih besar dari 0,05 dengan arah koefisien positif. Hal ini berarti bahwa kepemilikan manajerial sebagai variabel moderasi tidak berpengaruh terhadap hubungan antara tax management dan kualitas laba, sehingga $\mathrm{H}_{2}$ ditolak. Hal ini dikarenakan masih rendahnya saham yang dimiliki oleh pihak manajemen yang ikut andil dalam pengambilan keputusan. Secara individu kepemilikan manajerial juga tidak berpengaruh terhadap kualitas laba yang berarti ada atau tidak saham yang dimiliki oleh pihak manajemen perusahaan, kualitas laba tidak mengalami peningkatan dimata investor.

Rendahnya kepemilikan saham oleh manajemen mengindikasi bahwa praktik corporate governance di perusahaan Indo-nesia masih sangat rendah.

Kebanyakan saham perusahaan Indonesia masih didominasi oleh kepemilikan asing sehingga manajemen perusahaan menjalankan peru-sahaan hanya untuk insentif saja. Menurut Jensen dan Meckling (1976) kepemilikan manajerial dapat mensejajarkan kepentingan manajemen dan pemegang saham, akan tetapi masih rendahnya kepemilikan manajerial tersebut akan dapat berdampak perilaku yang menyimpang dari tujuan perusahaan. Perilaku menyimpang tersebut secara tidak langsung akan dapat menurunkan kualitas laba perusahaan yang dapat merugikan kreditor, investor, dan pemerintah. Hasil ini tidak konsisten dengan penelitian yang dilakukan oleh Jumiati dan Ratnadi (2014) yang menemukan bahwa kepemilikan manajerial berpengaruh positif terhadap persistensi laba. Hasil yang berbeda juga ditemukan oleh Irawan dan Farahmita (2012) yang menemukan bahwa kepemilikan direksi berpengaruh negatif signifikan terhadap manajemen pajak perusahaan.

Pengaruh kepemilikan institusi memoderasi terhadap hubungan tax management dan kualitas laba. Variabel interaksi antara tax management dan kepemilikan institusi yang dilihat dari BTD*IO mempunyai nilai $t_{\text {hitung }}$ sebesar $-3,371$ dengan tingkat signifikansi sebesar 0,001 yang berarti lebih kecil dari 0,05 dengan arah koefisien negatif. Hal ini berarti bahwa kepemilikan institusi merupakan variabel moderasi yang berarti bahwa kepemilikan institusi memoderasi terhadap hubungan antara tax management dan kualitas laba, sehingga $\mathrm{H}_{3}$ diterima. Hasil penelitian ini berbeda dari perkiraan bahwa kepemilikan institusi akan memperlemah pengaruh tax management terhadap kualitas laba.

Hasil ini menunjukkan bahwa dalam tax planning, pembentukan anak perusahaan dan holding company di antaranya memiliki tujuan penghematan pajak melalui income shifting, sehingga sangat dimungkinkan keterlibatan principal melalui induk perusa-haan dalam kebijakan perpajakan 
perusahaan dalam satu grup. Anak perusahaan sebuah grup cenderung memiliki tarif pajak efektif lebih rendah dibandingkan perusahaan independen. Perusahaan induk secara strategis akan melakukan penggeseran laba yang dilaporkan (income shifting) di antara perusahaan afiliasi untuk menurunkan tarif pajak efektif secara keseluruhan (Gramlich et al., 2002). Hasil penelitian ini tidak konsisten dengan Sumomba (2013) yang menemukan bahwa kepemilikan isntitusi tidak berpengaruh terhadap manajemen pajak. Begitu juga dengan Firman (2013) yang menemukan bahwa interaksi kepemilikan institusi dengan booktax differences tidak berpengaruh terhadap hubungan antara book-tax differences dan persistensi laba.

Variabel kontrol arus kas operasi yang dilihat dari CFO mempunyai nilai $t_{\text {hitung }}$ sebesar -0,661 dengan tingkat signifikansi sebesar 0,511 yang berarti lebih besar dari 0,05 dengan arah koefisien negatif. Hal ini berarti bahwa kualitas laba dalam penelitian ini tidak dipengaruhi arus kas operasi (CFO). Variabel kontrol ukuran perusahaan yang dilihat dari size mempunyai nilai $t_{\text {hitung }}$ sebesar 0,087 dengan tingkat signifikansi sebesar 0,931 yang berarti lebih besar dari 0,05 dengan arah koefisien positif. Hal ini berarti bahwa kualitas laba dalam penelitian ini tidak dipengaruhi oleh ukuran perusahaan (size). Variabel kontrol kinerja perusahaan yang dilihat dari ROA mempunyai nilai $t_{\text {hitung }}$ sebesar 5,173 dengan tingkat signifikansi sebesar 0,000 yang berarti lebih kecil dari 0,05 dengan arah koefisien positif. Hal ini berarti bahwa kualitas laba dalam penelitian ini dipengaruhi oleh kinerja perusahaan (ROA).

\section{SIMPULAN}

Tujuan dari penelitian ini adalah untuk menguji pengaruh tax management terhadap kualitas laba dan corporate governance sebagai variabel moderasi pada perusahaan manufaktur di Bursa Efek Indonesia tahun 2008-2013. Berdasarkan hasil penelitian dan pembahasan maka diperoleh kesimpulan tax management yang diproksikan dengan book-tax differences berpengaruh negatif terhadap kualitas laba. Hal ini berarti perusahaan rata-rata melaporkan laba sebelum pajak yang lebih besar dibandingkan dengan laba fiskal.

Selanjutnya, kepemilikan manajerial tidak berpengaruh pada hubungan tax mana-gement dan kualitas laba. Hal ini berarti ada atau tidaknya kepemilikan manajerial tidak akan mempengaruhi kualitas laba perusahaan di mata investor. Kepemilikan institusi memoderasi hubungan tax management dan kualitas laba. Hal ini berarti dengan pembentukan anak perusahaan dan holding company, perusahaan memiliki tujuan penghematan pajak melalui income shifting, sehingga sangat dimungkinkan keterlibatan principal melalui induk perusahaan dalam kebijakan perpajakan perusahaan dalam satu grup.

Penelitian ini memiliki beberapa keterbatasan yaitu: pertama, jumlah sampel yang digunakan dalam penelitian relatif sedikit, yaitu 12 perusahaan manufaktur sehingga hasil penelitian ini tidak dapat digunakan sebagai dasar generalisasi. Hal ini disebabkan beberapa data yang dibutuhkan dalam penelitian ini tidak lengkap. Kedua, penelitian ini hanya berfokus pada perusa-haan yang mendapatkan laba selama periode pengamatan.

Beberapa pertimbangan yang perlu diperhatikan dalam mengembangkan dan memperluas penelitian selanjutnya, meliputi: pertama, penelitian berikutnya perlu mem-pertimbangkan pengaruh tax management yang meliputi perbedaan permanen dan temporer terhadap kualitas laba. Kedua, penelitian selanjutnya sebaiknya meng-gunakan sampel perusahaan baik yang laba maupun rugi dan mengembangkan model penelitian ini pada sektor lain selain sektor manufaktur. Ketiga, penelitian 
selanjutnya dapat menggunakan proksi tax management yang lain seperti cashETR yang digunakan oleh Irawan dan Faramita (2012). Terakhir, perlu kiranya di penelitian berikutnya untuk menambahkan mekanisme corporate gover-nance yang dapat mepengaruhi kualitas laba.

\section{DAFTAR PUSTAKA}

Bellovary, N., A. B. Farris, D. Hackel, M. Kumershek, B. Pederson., dan C. Thistle. 2005. Current corporate income tax developments: Northeast Region. Journal of State Taxation, Summer, 23 (1), 51 -.

Boynton, C. E., P. S. Dobbins, G. A. Plesko. 1992. Earning management and the corporate alternative minimum tax. Journal of Accounting Research, 30, 131-153.

Bursa Efek Indonesia. 2015. www.idx.co.id, diunduh Mei 2015

Chariri, A. dan I. Ghozali. 2007. Teori Akuntansi. Semarang: Universitas Diponogoro.

Chen, S., X. Chen, Q. Chen, dan T. Shevlin. 2008. Are family firms more tax aggressive than non-family firms?. Working Paper. Foster School of Business, University of Washington.

Desai, M. A. dan D. Dharmapala, 2004. Corporate tax avoidance and high-powered incentives. Working Papers. Departement of Economics, Univers-ity of Connecticut.

Deviana, B. S. P. 2009. Kemampuan beban pajak tangguhan dan beban pajak masa kini dalam mendeteksi manajemen laba pada saat seasoned equity offerings. Skripsi, Universitas Diponogoro.

Djamaluddin, S., Rahmawati, dan H. T. Wijayanti. 2008. Analisis Pengaruh Perbedaan antara Laba Akuntansi dan Laba Fiskal terhadap persistensi Laba, Akrual, dan Arus Kas pada Perusahaan Perbankan yang Terdaftar di Bursa Efek Jakarta. Working Papers. Universitas Sebelas Maret, Surakarta.

Fanani, Z. 2010. Analisis faktor-faktor penentu persistensi laba. Jurnal akuntansi dan keuangan Indonesia, 7 (1), 109-123.

Firman, A. M. 2013. Kualitas laba, Tax management dan Corporate Governance. Paper Dipresentasikan pada Simposium Nasional Akuntansi XVI, Manado.

Givoly, D, C. K. Hayn dan S. P. Katz. 2010. Does Public Ownership of Equity Improve Earning Quality. The Accounting Review, 85 (1), 195-225.

Ghozali, I. 2013. Aplikasi Analisis Multivariate dengan Program IBM SPSS 21. Semarang: Universitas Diponogoro.

Hanlon, M. 2002. The Persistence of Earnings, Accruals, and Cashflows when Firms have Large Book-Tax Differences. Doctoral Dissertation, University of Washington.

Irawan, H. P. dan A. Farahmita. 2012. Pengaruh kompensasi manajemen dan corporate governance terhadap manajemen pajak perusahaan. Paper Dipresentasikan pada Simposium Nasional Akuntansi XV, Banjarmasin.

Ikatan Akuntan Indonesia. 2014. Pernyataan Standar Akuntansi Keuangan No. 46 tentang Akuntansi Pajak Pengha-silan. Jakarta.

Jensen, M. C. dan W. H. Meckling. 1976. Theory of the Firm: Managerial Behavior, Agency Costs and Ownership Structure. Journal of Financial Economics, Oktober, 1976, Vol. 3, No. 4, pp. 305-360. Jumiati, F. dan N. M. D. Ratnadi. 2014. Pengaruh kepemilikan manajerial dan book tax differences terhadap persistensi laba. EJurnal Akuntansi Universitas Udayana, 8 (2), 91-101.

Klein, A. 2002. Audit Committee, Board of Director Characteristics and Earning Management. Working Paper. Law and Economics Research Paper Series. New York University.

Lev, B. dan D. Nissim. 2004. Taxable Income, future earnings and equity values. The Accounting Review, 79 (4), 1039-1074.

Manzon, G. B. dan G. A. Plesko. 2002. The Relation between Financial and Tax Reporting Measures of Income. Working Paper. MIT Sloan School of

Minnick, Kristina. Tracy Noga. 2009. Do Corporate governance characteristic influence tax management?. Bentley university.

Plesko, G. A. 2004. Corporate Tax Avoidance and the properties of corporate earnings. National tax Journal, 57 (3), 729-737.

Republik Indonesia. 2008. Undang-undang No. 36 Tahun 2008 tentang Pajak Penghasilan.

Sumomba, C. R. 2013. Pengaruh Corporate Governance pada Manajemen Pajak pada Perusahaan Non Keuangan yang terdaftar di Bursa Efek Indonesia. Tesis, Universitas Dipone-goro.

Wijayanti, H. T. 2006. Analisis Perbedaan Antara Laba Akuntansi dan Laba Fiskal Terhadap Persistensi Laba Akrual dan Arus Kas. Paper Dipresentasikan pada Simposium Nasional Akuntansi IX, Padang.

Yunianto, A. 2013. Pengaruh Penggantian Manajemen, Dewan Komisaris Inde-penden, Kepemilikan Managerial, Kepemilikan Institusional, Dan Kualitas Audit Terhadap Manajemen Laba. Jurnal Akuntansi dan Investasi, 14 (2), 156-172. www.economy.okezone.com. diakses April 2015 www.ortax.org. diakses Februari 2015 